\title{
Bariery w edukacji osób z autyzmem
}

\section{Wprowadzenie}

Realizacja idei inkluzji społecznej i włączanie osób z niepełnosprawnością w główny nurt życia społecznego sprawiło, że prawo do edukacji dorosłych osób z autyzmem zostało przyjęte jako społeczne zobowiązanie do jego respektowania i tworzenia warunków równych szans edukacyjnych tych osób.

Istotną rolę w podjęciu działań na rzecz likwidacji barier w dostępie do edukacji osób z niepełnosprawnością odgrywa Konwencja Praw Osób Niepełnosprawnych i jej ratyfikacja przez Polskę w 2012 roku. Przyjęto w niej, że to właśnie bariery, jakie napotykają osoby z dysfunkcją, utrudniają im pełny i skuteczny udział w życiu społeczeństwa, na zasadzie równości $\mathrm{z}$ innymi osobami. W art. 24 ust. 5 Konwencji zawarte zostały zobowiązania dotyczące obszaru edukacji:

Państwa Strony zapewnią, że osoby niepełnosprawne będą miały dostęp do powszechnego szkolnictwa wyższego, szkolenia zawodowego, kształcenia dorosłych i uczenia się przez całe życie, bez dyskryminacji i na zasadzie równości z innymi osobami. W tym celu Państwa Strony zagwarantują, że zapewnione będą racjonalne usprawnienia dla osób niepełnosprawnych ${ }^{1}$.

1 Konwencja o prawach osób niepełnosprawnych z dnia 13 grudnia 2006 r., Dz.U. 2012, poz. 1169. 
Szkoły wyższe, na mocy ustawy Prawo o szkolnictwie wyższym, zostały zobligowane do stwarzania osobom z niepełnosprawnością warunków do pełnego uczestnictwa w procesie kształcenia i badaniach naukowych ${ }^{2}$. Tym samym uczelnie rozpoczęły stopniowe dostosowywanie warunków edukacyjnych, wdrażając model edukacji włączającej na poziomie szkoły wyższej ${ }^{3}$.

Uchwałą Sejmu Rzeczypospolitej Polskiej z dnia 12 lipca 2013 r. przyjęta została także Karta Praw Osób z Autyzmem. Potwierdza się w niej prawo osób z autyzmem do łatwo dostępnej, bezpłatnej i adekwatnej edukacji, dostosowanej do możliwości i potrzeb ucznia $\mathrm{z}$ autyzmem i pozwalającej na pełnienie ról społecznych, w tym szczególnie ról zawodowych ${ }^{4}$.

Istnieją zatem podstawy prawne gwarantujące i deklarujące obowiązek zapewnienia osobom $\mathrm{z}$ autyzmem równego dostępu do edukacji na wszystkich jej szczeblach, w tym także w szkolnictwie wyższym, zawodowym oraz w obszarze całożyciowej edukacji dorosłych. Jednocześnie, mimo szerokiego zainteresowania problematyką autyzmu, podkreślania wielospecjalistycznego podejścia w zakresie diagnozy i terapii, zaangażowania specjalistów wielu dziedzin, intensywnie realizowanej wczesnej interwencji i wypracowanych oddziaływań w zakresie rozwiązań edukacyjnych, wciąż istnieje problem przygotowania i włączania nawet najlepiej funkcjonujących dorosłych osób $\mathrm{z}$ autyzmem do uczestnictwa w życiu społecznym i podejmowania aktywności zawodowej.

Niewątpliwie istotnym problemem jest odmienność i różnorodność funkcjonowania osób $\mathrm{z}$ autyzmem. $\mathrm{Z}$ tego też względu stosowane jest również pojęcie „zaburzeń ze spectrum autyzmu (autism spectrum disorders, ASD), do którego zaliczane są grupy podobnych zaburzeń obejmujących autyzm, autyzm atypowy oraz Zespół Aspergera. Zasadniczo charakteryzują się zróżnicowanym nasileniem objawów w dwóch głównych obszarach, obejmujących zaburzenia interakcji

2 Ustawa z dnia 27 lipca 2005 r. - Prawo o szkolnictwie wyższym, Dz.U. 2005, nr 164, poz. 1365 z późn. zm., art. 94 ust. 4 a.

3 Zasada równego traktowania - prawo i praktyka. Dostępność infrastruktury publicznej dla osób z niepełnosprawnością. Analiza i zalecenia, „Biuletyn Rzecznika Praw Obywatelskich" 2015, nr 5, s. 5.

4 Uchwała Sejmu Rzeczypospolitej Polskiej z dnia 12 lipca 2013 r. Karta Praw Osób z Autyzmem, M.P. 2013 poz. 682. 
społecznych i komunikacji oraz ograniczony, sztywny i stereotypowy repertuar zachowań, zainteresowań i aktywności ${ }^{5}$. Ostatecznie, zespół objawów występujących u danej osoby, może tworzyć obraz funkcjonowania całkowicie odmienny od innej, a badacze podkreślają, że nie znajdziemy dwóch jednakowych osób dotkniętych tym zaburzeniem ${ }^{6}$. Sprawia to, że każda osoba (uczeń/student) z autyzmem stanowi nowe wyzwanie, niezależnie od posiadanego wcześniej doświadczenia. Tym samym, adaptowane czy przyjęte wcześniej rozwiązania czy zasady wspierania, mogą okazać się nieadekwatne wobec potrzeb kolejnej osoby.

Drugim, wciąż podkreślanym problem, jest znikoma wiedza na temat potrzeb i możliwości wsparcia tej grupy osób, czego konsekwencją jest fakt, wskazywany przez R. Stefańską-Klar, że w wielu biurach ds. niepełnosprawnych funkcjonujących przy szkołach wyższych, w ogóle nie wyróżnia się problemu studentów z autyzmem, choć obecnie, w wielu krajach takie rozwiązania są wprowadzane. Niestety, również i tam społeczna i edukacyjna sytuacja dorosłych osób dotkniętych autyzmem (choćby w lekkim stopniu), pozostawia wiele do życzenia?.

W literaturze niewiele miejsca poświęca się edukacji dorosłych osób $\mathrm{z}$ autyzmem, w tym także okresowi dorosłości tej grupy osób. Lidia Szmania analizuje liczne trudności w nawiązywaniu relacji w dorosłym życiu przez osoby z autyzmem wysokofunkcjonującym i Zespołem Aspergera. Wskazuje, że ich pasje i wąskie zainteresowania nie sprzyjają nawiązywaniu relacji i często realizowane są w samotności. Jednocześnie zauważa, że stanowią istotny walor edukacyjny sprawiają, że potrafią podporządkować im całe swoje życie, rozwijając się w wąskiej dziedzinie wiedzy i specjalizacji zawodowej ${ }^{8}$.

$5 \quad$ F. Rybakowski i in., Zaburzenia ze spektrum autyzmu - epidemiologia, objawy, wspótzachorowalność, rozpoznawanie, „Psychiatria Polska” 2014, nr 48(4), s. 65; A. Waś i in., Czy to autyzm? Trudności w diagnozie. „Neurologia Dziecięca” 2011, t. 20, nr 41, s. $105-110$.

6 A. Płusa, Wsparcie edukacyjne dziecka z autyzmem, „Studia Pedagogiczne. Problemy Społeczne, Edukacyjne i Artystyczne" 2017, t. 30, s. 40.

$7 \quad$ R. Stefańska-Klar, Studenci z autyzmem i zespołem Aspergera. Funkcjonowanie, przyczyny sukcesów i porażek, warunki skutecznego wspierania, [w:] I. Bieńkowska (red.), $W$ kręgu resocjalizacji i wybranych zagadnień rozwoju oraz funkcjonowania osób niepełnosprawnych, Wydawnictwo Scriptum, Gliwice - Kraków 2010, s. 91-107.

8 L. Szmania, Możliwości i ograniczenia osób z zaburzeniami spektrum autyzmu w realizacji własnych wizji dorosłości, Studia Edukacyjne, Wydawnictwo Uniwersytetu Adama Mickiewicza w Poznaniu, Poznań 2016, 39, s. 343. 
Badania obejmujące studentów z autyzmem prowadziła R. Stefańska-Klar. Zwraca uwagę na takie cechy studentów $\mathrm{z}$ autyzmem, które mogą pomóc w studiowaniu, a czasami nawet pozwalają uzyskać przewagę nad innymi studentami tj. doskonałe zdolności pamięciowe, pasja do szczegółowego badania wąskich obszarów wiedzy, niezwykle silna motywacja, wola i niezależność działania, dążenie do wyznaczonego celu, pomimo zakłóceń, utrudnień i przeszkód. Wskazuje także na liczne trudności doświadczane przez studentów, które w każdym przypadku były typowe dla spektrum autyzmu, a których osoba nie była w stanie sama pokonać, i nie otrzymała żadnego wsparcia z zewnątrz, aby dany problem rozwiązać lub trudność pokonać9.

\section{Założenia badawcze}

Obecnie coraz więcej osób z diagnozą zaburzeń ze spektrum autyzmu realizuje edukację w systemie integracyjnym lub włączającym, uzyskując średni i wyższy poziom wykształcenia. Wiąże się to z faktem, że około połowa tych osób nie posiada intelektualnych ograniczeń do uczenia się ${ }^{10}$, a wraz z wiekiem i pod wpływem prowadzonej terapii oraz edukacji, objawy autyzmu stają mniej nasilone, a osoby te uczą się coraz lepiej radzić i adaptować się do warunków środowiska, w którym żyją. Jednak dysfunkcje są wciąż obecne, a w relacji z niedostosowanym do ich potrzeb środowiskiem fizyczny, społecznym i edukacyjnym, stanowią realne zagrożenie doświadczania barier, których samodzielnie nie są w stanie przezwyciężać.

Celem badań było rozpoznanie sytuacji edukacyjnej dorosłych osób z autyzmem, identyfikacja doświadczanych barier oraz potrzeb w zakresie wsparcia społecznego i edukacyjnego. Materiał badawczy został zgromadzony w ramach projektu badawczego, dotyczącego diagnozy potrzeb osób z niepełnosprawnością, realizowanego na zlecenie Urzędu Miasta Białegostoku ${ }^{11}$. Na potrzeby opracowania wykorzystano

9 R. Stefańska-Klar, Studenci z autyzmem..., s. 5-7.

10 I. Nowakowska, E. Pisula, Wiedza na temat zaburzeń ze spektrum autyzmu i opinie dotyczace edukacji włączającej dzieci z tymi zaburzeniami u nauczycieli szkół podstawowych oraz studentów kierunków nauczycielskich, „Człowiek - Niepełnosprawność - Społeczeństwo" 2018, nr 2, s. 29.

11 M. Zemło i in., W kierunku inkluzji społecznej. Potrzeby osób z niepetnosprawnościa w mieście Białystok, Wydawnictwo Naukowe Katedra, Białystok - Gdańsk 2018. 
wyniki badań dotyczące 13 dorosłych osób z autyzmem, w wieku od 18 do 35 lat, które po ukończeniu szkoły średniej podejmowały dalszą edukację. Większość badanej grupy stanowili mężczyźni (11 osób). Były to osoby z głębszym (umiarkowanym i znacznym) stopniem niepełnosprawności. Materiał badawczy został pozyskany za pomocą wywiadów ustrukturyzowanych, przeprowadzonych z osobami z autyzmem lub ich opiekunami. Wywiady były rejestrowane w programie Windows Media Player, następnie dokonywano ich transkrypcji w programie Word. W trakcie spotkań nawiązywano bardzo dobry kontakt ze wszystkimi uczestnikami badań, stworzono atmosferę sprzyjającą ich poczuciu bezpieczeństwa, życzliwości i zaufania, co umożliwiło przeprowadzenie wywiadu pogłębionego. Uzyskany tą drogą materiał empiryczny został poddany analizie jakościowej z elementami analizy narracji respondentów.

\section{Doświadczanie barier w edukacji dorosłych osób ze spektrum autyzmu - wyniki badań własnych}

Analizując sytuację edukacyjną przedstawioną przez badane osoby z autyzmem, należy przede wszystkim podkreślić, że przedstawia się ona w sposób zróżnicowany. Część badanych osób, po ukończeniu szkoły średniej (liceum integracyjne), nie kontynuowała nauki, pozostałe realizowały ją w szkołach policealnych lub podjęły studia. Były też takie, które po ukończeniu studiów magisterskich, kontynuowały naukę na studiach doktoranckich. Ich doświadczenia są indywidualne i niepowtarzalne, ukazują tym samym różnorodne zjawiska, stanowiące realne zagrożenie i bariery uczestnictwa dorosłych osób z autyzmem w edukacji.

\section{„Porzucenie edukacyjne” dorosłych osób z autyzmem}

Analiza sytuacji edukacyjnej badanych osób wskazuje, że wraz z dorosłością, kończy się etap zabezpieczenia ich potrzeb, bezpiecznego azylu, a także intensywnie realizowanej rehabilitacji. Oczekuje się bowiem, że osoby te, do tego czasu powinny rozwinąć swoje możliwości na tyle, by dalej radzić sobie samodzielnie. Jak wskazują autorzy raportu dotyczącego sytuacji dorosłych osób z autyzmem w Polsce, trudność sytuacji tych osób wynika z faktu, iż ich niepełnosprawność 
ma charakter w dużym stopniu ukryty. Określana jest jako „efekt góry lodowej“, polegający na dysproporcji między widocznymi dla otoczenia objawami autyzmu, a rzeczywistymi trudnościami doświadczanymi przez takie osoby. To zjawisko powoduje, że często otoczenie bezpodstawnie oczekuje od osoby z autyzmem, aby przystosowała się do sytuacji i warunków, przeceniając jej możliwości i nie dostrzegając potrzeb w zakresie koniecznego wsparcia ${ }^{12}$. Tymczasem zmiana środowiska edukacyjnego, wraz z perspektywą pozostania bez dotychczas posiadanego zabezpieczenia wspierającego, dla niektórych osób staje się zasadniczym powodem rezygnacji z dalszej edukacji.

Tak sytuację syna przedstawia rodzic:

Byliśmy zbyt zmęczeni, żeby wchodzić w obszar, który nie daje gwarancji poczucia bezpieczeństwa, a wręcz przeciwnie, stanowi duże ryzyko. Jak [syn] skończył szkołę średnią, wyszukiwał w Internecie różne szkoły, bardzo chciał kontynuować naukę, ale i dla nas i dla niego nie było to proste (W19A).

Ukończenie szkoły średniej, jest więc momentem nie tylko ważnych wyborów i decyzji edukacyjnych, ale także momentem radykalnej zmiany związanej z pozbawieniem dotychczas obecnego wsparcia oraz obawami i brakiem orientacji, co do możliwości jego uzyskania. $\mathrm{Z}$ wypowiedzi wynika również, że nie działa poradnictwo edukacyjno -zawodowe, a orientację o możliwościach edukacyjnych zdobywają korzystając z Internetu.

Jak się okazuje, dokonane wybory nie zawsze są trafne, być może nie najlepsze $\mathrm{z}$ możliwych, co ostatecznie zniechęca do kontynuacji nauki. Przykładem jest sytuacja kolejnej osoby, która po ukończeniu integracyjnej szkoły średniej i zdaniu matury, podjęła naukę w policealnej szkole zaocznej.

„Rok byłam w zaocznej szkole administracji, ale nie ukończona. Poszłam do pracy, to zrezygnowałam w maju tamtego roku (...), albo to albo to. Nudne to było, wolałabym raczej w stronę grafiki” (W17A).

Również w sytuacji niepowodzeń doświadczanych podczas studiów, podejmują kolejne kierunki kształcenia, nie posiadając konkretnych planów ani dążeń w celu uzyskania przygotowania do pracy, a raczej, jak to określa były student, na zasadzie robienia czegokolwiek.

12 Autyzm - Sytuacja Dorosłych. Raport 2013, Instytut Rozwoju Służb Społecznych, Fundacja SYNAPSIS, Warszawa 2014, s. 251. 
Miałem maturę to się uczyłem. Zacząłem naukę w „Żaku”, technik rachunkowości. Skończyłem ten kierunek w systemie zaocznym, mimo że nie pracowałem. Było ciężko, ale udało mi się zdać. Na późniejszych semestrach te grupy były mniejsze, chociaż to było lepsze. Jeszcze się uczę [kolejna szkoła policealna], myślę, że mi to się przyda. Na razie z tego korzystam, opcję mam (W16A).

W rzeczywistości edukacyjnej prezentowanych osób z autyzmem dostrzega się sytuację, którą można określić „porzuceniem edukacyjnym" - to odcięcie od dotychczasowego wsparcia, brak poradnictwa, wręcz brak zainteresowania ich dalszym rozwojem i losem, w konsekwencji ich osamotnienie i zagubienie. Ich samodzielne kierowanie swoim rozwojem sprowadza się raczej do próbowania własnych sił poradzenia sobie i poszukiwania jakichkolwiek możliwości niż realizacji zaplanowanej ścieżki edukacyjno-zawodowej. Nic też dziwnego, gdyż planowanie nie jest mocną stroną osób z autyzmem, a możliwości wyboru dostosowanej do ich potrzeb oferty edukacyjnej i zawodowej są niewielkie.

\section{Formalne, sztywne i wykluczające procedury}

Osobom z autyzmem bardzo często trudno jest podporządkować się formalnie narzuconym procedurom. Zostało to dostrzeżone już na etapie diagnozy psychologicznej, gdy okazało się, że funkcjonowania tych dzieci nie da się ocenić stosując formalne procedury testowe. Konieczne okazało się zastosowanie alternatywnych warunków, zrezygnowanie ze sztywnych procedur, co pozwoliło na przezwyciężanie tego problemu ${ }^{13}$. Niestety, sytuacja ta dotyczy także innych formalnych procedur, z jakimi stykają się w życiu, a także w procesie edukacji. Przykładem jest niedopuszczenie do zdawania egzaminu maturalnego uczennicy z autyzmem, ze względu na potrzebę pisania wspomaganego z udziałem asystenta. Zasadniczym, postawionym jej warunkiem było asystowanie przez osobę obcą, a nie przez rodzica, który dotychczas pełnił funkcje asystenta. Tak sytuację przedstawia matka, niemówiącej osoby z autyzmem.

Z powodu pisania (konieczności wspomagania) nie została dopuszczona do matury, skończyła się edukacja. Ona była wtedy pełna nadziei, optymistycznie

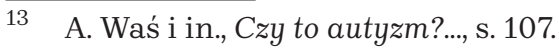


nastawiona, kontaktowa. Zabrakło asystenta, od początku nie znaleźliśmy nikogo. Nie było innej osoby oprócz rodziców do wspomagania pisania, z tego powodu nie dopuszczono do matury. Próbowałam puszczać jej rękę, wymusić samodzielne pisanie, ale to tak się nie da. Byliśmy pełni nadziei, ona sama też, ale potem jak nie dopuścili do matury przez te pisanie... ach... (W12A).

Należy podkreślić, że była to osoba szczególnie zdolna, dla której uczenie się było największą przyjemnością, jakiej doznawała w swoim życiu, a uczyła się głównie sama zaskakując innych swoją wiedzą. Obowiązek szkolny realizowała w formie kilku godzin nauczania indywidualnego.

W szkole, w klasie VI panie tylko egzaminowały ją. Pisała ze wspomaganiem, trochę ze mną, trochę z mężem. Napisała tak, że dwóch punktów zabrakło do $100 \%$ (egzamin gimnazjalny). Sama zrealizowała obowiązek szkolny ucząc się z książek trzy lata starszej siostry. Aż trzęsła się do tych książek (W12A).

W przypadku drugiej osoby, również o wybitnych zdolnościach uczenia się, sytuacja potoczyła się zupełnie inaczej. Zasadniczym warunkiem stała się zdolność do współpracy z asystentem wspomagającym pisanie. Otworzyło to drogę do dalszej edukacji, pomyślnie ukończonych studiów magisterskich i rozpoczęcia studiów doktoranckich. Jednak jeszcze wiele razy musiał udowodnić, przekonać innych do tego, że treści pisane z udziałem osoby wspomagającej, są formułowane przez niego, a nie przez podtrzymującego łokieć (asystującego ) rodzica (W21A).

Przedstawiona sytuacja, jest drastycznym przykładem, gdzie o losach edukacyjnych i życiowych młodej osoby z autyzmem, zadecydowały formalne procedury, a nie jej wręcz wyjątkowe możliwości i osiągnięcia edukacyjne.

Kolejny przykład dotyczy konieczności podporzadkowania się formalnym wymaganiom, nieuwzględniającym funkcjonowania osób $\mathrm{z}$ autyzmem, w zakresie ich odmiennego sposobu uczenia się:

„Nauczycielka miała swój sposób widzenia i nie pozwalała funkcjonować inaczej. Na przykład, jeżeli rozwiązałem zadanie innym sposobem potrafiła mi nie uznać punktacji, mimo iż wynik i rozwiązanie były poprawne" (W06A).

Wykluczający jest także fakt, że w procedurach i formach pomocy oferowanej studentom, nie wyszczególnia się osób z autyzmem, co 
sprawia, że w zasadzie nie wiedzą, na jaką pomoc mogą liczyć, o co się ubiegać.

„W technikum miałem nauczanie indywidualne i to bardzo pomogło mi. Tu mówili, że jest możliwość nauczania indywidualnego. Ale to była całkowita fikcja. Wypytywaliśmy się u opiekuna roku, okazało się, że wcale nie ma takiej opcji" (W16A).

Chociaż podkreśla się, że katalog form wsparcia możliwych do zastosowania wobec studentów $\mathrm{z}$ niepełnosprawnością nie jest zamknięty ${ }^{14}$, to jego rozszerzanie w odpowiedzi na potrzeby studentów $\mathrm{z}$ autyzmem, nie jest oczywiste.

\section{Standardowe warunki i oczekiwania wobec osób $z$ autyzmem}

Dorosłość osób z autyzmem nie zawsze wiąże się z pełną samodzielnością $\mathrm{w}$ poradzeniu sobie $\mathrm{z}$ codziennym funkcjonowaniem, zwłaszcza w nowym środowisku. Czują się „zagubieni” w nowej przestrzeni, nie wiedzą z czym, do kogo i w jaki sposób mają się zwrócić. Tymczasem oczekuje się, że jako osoby dorosłe, powinni sami zadbać o swoje potrzeby, ewentualnie przedstawić je i zwrócić się o pomoc. Niestety tak nie jest.

„Osoby z autyzmem, dorosłe osoby z autyzmem, to nie to, że one o te swoje potrzeby ubiegają się, domagają się czegoś, wręcz przeciwnie, można powiedzieć wycofują się do takiego swojego minimalnego repertuaru i w gruncie rzeczy, żeby tutaj z czymś wyjść do nich, to trzeba jednak ich po prostu zachęcić do tego wręcz" (W10A).

Dlatego zazwyczaj starają się radzić samodzielnie, choć nie zawsze skutecznie. Zwracają się o pomoc, gdy zostaną określone przysługujące im formy i zasady pomocy, nie wychodząc raczej z własnymi propozycjami. Niestety bywa, że nie otrzymują żadnego wsparcia, a ich „zagubienie” nie spotyka się z zainteresowaniem.

Tak swoją rezygnację ze studiów wyjaśnia badany mężczyzna:

14 Przykładowy katalog wydatków z dotacji na wsparcie procesu kształcenia i prowadzenia badań osób z niepełnosprawnościami, Ministerstwo Nauki i Szkolnictwa Wyższego, www.gov.pl (dostęp: 29.11.2019). 
„Uczyłem się na Politechnice, jako informatyk, ale nie dałem rady, po roku zrezygnowałem z nauki. Myślę , że się nie nadaję... też. Na początku było trudno, czasem był problem, kiedy sale się zmieniały, gdy w innym budynku były zajęcia (przyznaje też, że zdarzało się, że nie potrafił znaleźć sali i nie dotarł na zajęcia)" (W16A).

Zdarza się, że osoby z autyzmem, nie mówiąc nic nikomu, po prostu rezygnują z edukacji „znikając”, bądź informują o decyzji, której jednak nie chcą wyjaśniać czy uzasadniać.

Kluczowe w tych sytuacjach jest jednak wsparcie. Tak o sobie mówi jeden ze studentów z Zespołem Aspergera:

„Mama się nie poddała, mimo że były przypadki, że po prostu uczniowie musieli podawać się do dymisji, ja skończyłem maturę, mimo że nikt w to nie wierzył i moge potwierdzać, że przynajmniej naukowy Mount Everest został zdobyty" (W22A).

Na ogólne problemy wynikające $\mathrm{z}$ braku dostosowań w kształceniu dorosłych osób z autyzmem zwraca także uwagę opiekun, wyjaśniając rezygnację $\mathrm{z}$ dalszej edukacji syna.

Czyli można powiedzieć, że gdyby były jakieś formy na tym poziomie, (...) dla dorosłych, by można było te treści edukacyjne w jakichś sposób zmodyfikować, zastąpić pewne rzeczy, z pewnych zrezygnować, uzupełnić o takie, w których syn by dobrze sobie radził, mógłby się rozwijać, zrezygnować z tego co jest w jego przypadku nawet i niemożliwe (W19A).

Mimo trudności związanych z niedostosowaniem warunków edukacji do ich potrzeb, wiele osób realizuje kolejne etapy edukacji. Są osoby, które przyzwyczajają się do niedogodności, adaptują się do warunków i nie mają z tym większych problemów:

„Wydaje mi się, że na początku miałem problem z większą grupą. Obecnie wydaje mi się, że nie. Natomiast jeśli chodzi o dźwięki, to przywykłem już, że jest głośno, ze względu na dwójkę rodzeństwa. Teraz nie jest to dla mnie żaden problem" (W06A).

Istotna wydaje się być wiara innych w możliwości tych osób i ich wsparcie. Jednakże częstym problem jest brak zaufania i zaniżona ocena możliwości osób $\mathrm{z}$ autyzmem, a jedynymi osobami znającymi ich rzeczywiste możliwości są rodzice, niestety, niemający żadnych możliwości zaprezentowania i przekonania do swoich dorosłych już dzieci. 


\section{Lekceważenie, naruszanie przekonań światopoglądowych osób z autyzmem}

Niektóre osoby z autyzmem posiadają bardzo silne, czasem wydawać się może, że wręcz obsesyjne zainteresowania, w tym także przekonania np. religijne. Badany student wskazuje, że głoszone treści podczas wykładów, naruszały jego przekonania religijne i światopoglądowe na tyle, że zakłócało to jego funkcjonowanie emocjonalne i zdolność uczenia się.

„Był taki przedmiot, omawiany na temat chrześcijaństwa, ale to było z chrześcijaństwa raczej szydzenie niż omawianie (...). Te trudności wynikają nie tyle z mojej niepełnosprawności, ale światopoglądu głoszonego na uniwersytecie" (W07A).

Kwestie tego typu mogą być mało istotne np. na kierunkach ścisłych, ale jeżeli znajdą się one w treściach programowych, mogą stać się nawet zasadniczą barierą w uczeniu się i czynnikiem zakłócającym funkcjonowanie psychiczne.

\section{Brak zaufania i wiary w możliwości osób z autyzmem}

Nawet osoby posiadające wysokie osiągnięcia edukacyjne, spotykają się podejrzliwością co do ich możliwości, traktowane bywają w sposób wskazujący na dopatrywanie się niepełnosprawności intelektualnej.

„Wszystko jest trudne, i dzisiaj jest trudno. On wyczuwa daną osobę i wie która jak go traktuje i (...), która uważa go za upośledzoną osobę. Wtedy już nic nie zrobi dla tamtej osoby, się nie sprzeda na pewno" (W21A).

Kolejny student podkreśla, że nikt nie wierzył w jego możliwości, jedyne matka, która go wspierała.

„Ja skończyłem maturę, mimo że nikt w to nie wierzył” (W21A).

Osoby z autyzmem dostrzegają i wyczuwają, że oceniane są nisko, poniżej posiadanych możliwości, co zawsze jest trudne i przykre, może też prowadzić do kształtowania się zaniżonych przekonań o sobie. Zwłaszcza w sytuacji, gdy nauka rzeczywiście sprawia trudności, a otrzymywana pomoc jest niewystarczająca, mogą ostatecznie nabrać przekonań, że nie są w stanie się uczyć. Jak twierdzi jedna z badanych osób: 
„O nauce już nie chcę myśleć" (W16A).

Brak wiary i zaufania wobec osób z autyzmem jest szczególnie dotkliwy z uwagi także na występujący często wysoki samokrytycyzm ${ }^{15}$, tym samym łatwość ulegania negatywnym przekonaniom na swój temat.

Można zatem zgodzić się z R. Stefańską-Klar, że obecność wskazanych barier w edukacji osób z autyzmem i brak właściwego wsparcia, prowadzi również do trwałego porzucenia myśli o wykształceniu i zdobyciu jakiegokolwiek zawodu ${ }^{16}$.

\section{Podsumowanie}

Doświadczenia edukacyjne badanych osób z autyzmem po ukończeniu szkoły średniej wskazują, że spotykają się z licznymi trudnościami i barierami, będącymi bezpośrednim następstwem braku wsparcia i dostosowania warunków edukacji do ich potrzeb wynikających z niepełnosprawności. Mimo iż są w stanie sprostać wymaganiom edukacyjnym, nie są w stanie samodzielnie przezwyciężać doświadczanych utrudnień, a brak wsparcia w tym zakresie, jest głównym czynnikiem rezygnacji z edukacji, „wypadania” z sytemu edukacyjnego czy też zagubienia i niemożności znalezienia żadnej, skutecznie zrealizowanej ścieżki edukacyjnej na poziomie szkoły policealnej i studiów wyższych. Zidentyfikowane bariery wskazują istotne kierunki wsparcia, jakiego potrzebują te osoby po ukończeniu szkoły średniej. To przede wszystkim działające doradztwo edukacyjno-zawodowe wraz z rzetelnie przygotowaną informacją i ofertą wsparcia edukacyjnego w obszarze edukacji policealnej i w szkołach wyższych. Ważną kwestią jest wsparcie na etapie adaptacji w nowym środowisku edukacyjnym, identyfikacja potrzeb i pomoc w przezwyciężaniu doświadczanych

15 J. Kruk-Lasocka, Autyzm czy zespól Aspergera? Wpływ rozbieżności diagnostycznych na oddziaływania terapeutyczne, [w:] T. Gałkowski, J. Kossewska (red.), Autyzm wyzwaniem naszych czasów, Wydawnictwo Naukowe Akademii Pedagogicznej, Kraków 2000, s. 28.

16 R. Stefańska-Klar Uczniowie z zespołem Aspergera i pokrewnymi kondycjami w systemie edukacji. Jak wyrównać szanse edukacyjne uczniów, którzy sa „specyficznie inni”, [w:] J. Wojtaś (red.), Społeczne konteksty funkcjonowania osób z niepełnosprawnością, Państwowa Wyższa Szkoła Zawodowa im. Witelona w Legnicy, Legnica 2013, s. $141-151$. 
niedogodności związanych ze zmianą środowiska i zagubieniem w nim. Jest to okres szczególnie trudny dla osób z autyzmem, których mechanizmy adaptacyjne, za pomocą których „oswajają” świat, są zbyt kruche, stąd przeżywają wtedy wiele problemów wynikających z auty$\mathrm{zmu}$, jak i związanych $\mathrm{z}$ autyzmem trudności w uczeniu się ${ }^{17}$. Ważne jest także elastyczne i alternatywne podejście, zwłaszcza w sytuacjach, gdy standardowe procedury lub zasady ograniczają zastosowanie potrzebnych, a czasem wręcz niezbędnych rozwiązań, umożliwiających kontynuację nauki.

Istotnym wnioskiem jest potrzeba uświadomienia, że autyzm nie jest tożsamy z niepełnosprawnością intelektualną. Osoby z autyzmem w odmienny sposób odbierają i przetwarzają informacje, ale mogą mieć przy tym normalny lub wysoki iloraz inteligencji. Tym samym potrzeby dorosłych osób z autyzmem nie sprowadzają się wyłącznie do zapewnienia im miejsca opieki i zaspokajania podstawowych potrzeb egzystencjalnych (jak to może wynikać z uogólnionego, stereotypowego postrzegania autyzmu). Chorujący na autyzm, to także osoby posiadające znacznie wyższe możliwości, aspiracje, wymagające wobec siebie, także takie, które przy niewielkim nawet wsparciu, zdolne są osiągać wysokie wyniki edukacyjne i niezależność życiową. Postrzeganie tych osób przez pryzmat medycznej etykiety jaką jest autyzm, prawdopodobnie zawsze będzie narażało je na społeczny dystans i nieufność, nawet przy znacznej poprawie funkcjonowania oraz przystawania do społecznych standardów ${ }^{18}$

\begin{abstract}
Education of adults with autism creates great opportunities for further individual development of these people and their involvement in social and professional life. The aim of the study was to recognize the educational situation of adults with autism, identify the barriers experienced by them, and their needs in terms of social and educational support. The study involved 13 adults with autism who continued their education after high school.
\end{abstract}

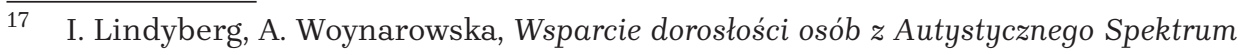
Zaburzeń w Polsce. Rozwiązania systemowe, możliwości i ograniczenia, „Niepełnosprawność. Dyskursy Pedagogiki Specjalnej" 2016, nr 24, s. 87.

18 A. Rzepkowska, Zespół Aspergera - społeczno-kulturowe konsekwencje diagnozy, „Zeszyty Wiejskie" 2014, nr 19, s. 143-153. 
The research material was obtained using a structured interview conducted with individuals with autism or their guardians.

The study presents the results of the research, showing a number of barriers faced by the subjects and their resultant needs in terms of support.

\section{Bibliografia}

Autyzm - Sytuacja Dorosłych. Raport 2013, Instytut Rozwoju Służb Społecznych, Fundacja SYNAPSIS, Warszawa 2014.

Konwencja o prawach osób niepełnosprawnych z dnia 13 grudnia 2006 r., Dz.U. 2012, poz. 1169.

Kruk-Lasocka J., Autyzm czy zespól Aspergera? Wpływ rozbieżności diagnostycznych na oddziaływania terapeutyczne, [w:] T. Gałkowski, J. Kossewska (red.), Autyzm wyzwaniem naszych czasów, Wydawnictwo Naukowe Akademii Pedagogicznej, Kraków 2000.

Lindyberg I., Woynarowska A., Wsparcie dorosłości osób z Autystycznego Spektrum Zaburzeń w Polsce. Rozwiązania systemowe, możliwości i ograniczenia, „Niepełnosprawność. Dyskursy Pedagogiki Specjalnej" 2016, nr 24.

Nowakowska I., Pisula E., Wiedza na temat zaburzeń ze spektrum autyzmu i opinie dotyczace edukacji włączającej dzieci z tymi zaburzeniami u nauczycieli szkół podstawowych oraz studentów kierunków nauczycielskich, „Człowiek - Niepełnosprawność - Społeczeństwo” 2018, nr 2.

Płusa A., Wsparcie edukacyjne dziecka z autyzmem, „Studia Pedagogiczne. Problemy Społeczne, Edukacyjne i Artystyczne" 2017, t. 30.

Rybakowski F. i in., Zaburzenia ze spektrum autyzmu - epidemiologia, objawy, współzachorowalność, rozpoznawanie, „Psychiatria Polska” 2014, nr 48(4).

Rzepkowska A., Zespół Aspergera - społeczno-kulturowe konsekwencje diagnozy, „Zeszyty Wiejskie” 2014, nr 19.

Stefańska-Klar R., Studenci z autyzmem i zespołem Aspergera. Funkcjonowanie, przyczyny sukcesów i porażek, warunki skutecznego wspierania, [w:] I. Bieńkowska (red.), W kręgu resocjalizacji $i$ wybranych zagadnień rozwoju oraz funkcjonowania osób niepełnosprawnych, Wydawnictwo Scriptum, Gliwice - Kraków 2010.

Stefańska-Klar R., Uczniowie z zespołem Aspergera i pokrewnymi kondycjami w systemie edukacji. Jak wyrównać szanse edukacyjne uczniów, którzy są „specyficznie inni”, [w:] J. Wojtaś (red.), Społeczne konteksty funkcjonowania osób z niepełnosprawnością, Państwowa Wyższa Szkoła Zawodowa im. Witelona w Legnicy, Legnica 2013. 
Szmania L., Możliwości i ograniczenia osób z zaburzeniami spektrum autyzmu w realizacji własnych wizji dorosłości, Studia Edukacyjne, Wydawnictwo Uniwersytetu Adama Mickiewicza w Poznaniu, Poznań 2016.

Uchwała Sejmu Rzeczypospolitej Polskiej z dnia 12 lipca 2013 r., Karta Praw Osób z Autyzmem, M.P. 2013, poz. 682.

Ustawa z dnia 27 lipca 2005 r. - Prawo o szkolnictwie wyższym, Dz.U. 2005, nr 164, poz. 1365 z późn. zm.

Waś A. i in., Czy to autyzm? Trudności w diagnozie. „Neurologia Dziecięca" 2011, t. 20, nr 41.

Zasada równego traktowania - prawo i praktyka. Dostępność infrastruktury publicznej dla osób z niepetnosprawnością. Analiza i zalecenia, „Biuletyn Rzecznika Praw Obywatelskich” 2015, nr 5.

Zemło M. i in., W kierunku inkluzji społecznej. Potrzeby osób z niepełnosprawnościa w mieście Białystok, Wydawnictwo Naukowe Katedra, Białystok - Gdańsk 2018.

\section{Netografia}

Przykładowy katalog wydatków z dotacji na wsparcie procesu kształcenia $i$ prowadzenia badań osób z niepetnosprawnościami, Ministerstwo Nauki i Szkolnictwa Wyższego, www.gov.pl (dostęp: 29.11.2019). 